\title{
BIOEDUSCIENCE
}

ISSN: 2614-1558

http://journal.uhamka.ac.id/index.php/bioeduscience

\section{Gonadal Differentiation of Nilem Fish (Osteochilus vittatus) utilizing Temperature Treatment}

\author{
Aulidya Nurul Habibah ${ }^{1 *}$, Rika P. C. Pertiwi² ${ }^{2}$ Titi Chasanah ${ }^{1}$ \\ ${ }^{1}$ Faculty of Biology, Jenderal Soedirman University, Jl. Dr. Soeparno 63, Grendeng, Karang Wangkal, Banyumas, Jawa Tengah, Indonesia, \\ 53122 \\ ${ }^{2}$ Faculty of Fisheries and Marine Science, Jenderal Soedirman University, Jl. Dr. Soeparno, Grendeng, Karangwangkal, Banyumas, Jawa \\ Tengah, Indonesia, 53122 \\ *Corespondent email: aulidya.nurul.habibah@unsoed.ac.id
}

\section{ARTICLE INFO}

Article history:

Received: 08 Okt 2020

Accepted: 10 Des 2020

Published: 31 Des 2020

\section{Keyword:}

Differentiation

Gonad

Growth

Teleost

Thermal

\section{A B S T R A C T}

Background: Gonad differentiation in some fish such as the tilapia group is influenced by environmental factors, namely temperature. This study aimed to determine the differentiation process of Nilem fish gonads (Osteochilus vittatus) under the influence of temperature. Methods: One day after fertilization (days post-fertilization/dpf) fish were exposed to different medium temperature ranges: $28-29{ }^{\circ} \mathrm{C}, 30-31{ }^{\circ} \mathrm{C}, 32-33{ }^{\circ} \mathrm{C}$ and room temperature as a control for 35 days each aquarium contained 110 fish. Every day the Nilem fish are given food containing $40 \%$ protein every 9 am and $4 \mathrm{pm}$. Thirty fish in each treatment were measured for body length at day $10 \mathrm{dpf}$ and day $35 \mathrm{dpf}$ to determine fish growth. Six fish $35 \mathrm{dpf}$ from each treatment were fixed in $70 \%$ alcohol for making histological preparations using the paraffin method, Haematoxylin-Eosin staining. Fish survival data growth data in the form of fish length were analyzed using ANOVA. Gonadal differentiation data were analyzed descriptively. Results: There was no significant difference in the growth of fish in all treatment and control groups. The average survival rate of fish in all treatment and control groups was $100 \%$. Observation of the gonads showed that the gonads were not differentiated in all treatment and control groups. Conclusions: The room temperature ranges up to $33^{\circ} \mathrm{C}$ supports the growth of Nilem fish with gonad development in the indifferent gonad stage.

Diferensiasi Gonad Ikan Nilem (Osteochilus vittatus) dengan Perlakuan Suhu

\section{A B S T R A K}

Background: Diferensiasi gonad pada beberapa ikan seperti pada kelompok tilapia dipengaruhi oleh faktor lingkungan, yaitu suhu. Tujuan dari penelitian ini adalah untuk mengetahui proses diferensiasi gonad ikan Nilem (Osteochilus vittatus) dengan pengaruh suhu. Metode: Ikan umur 1 hari paska fertilisasi (days post fertilisation/dpf) didedahkan pada kisaran suhu medium yang berbeda yaitu: $28-29{ }^{\circ} \mathrm{C}, 30-31^{\circ} \mathrm{C}, 32-33^{\circ} \mathrm{C}$ dan suhu ruang sebagai kontrol selama 35 hari masingmasing akuarium berisi 110 ikan. Setiap hari ikan Nilem diberi pakan yang mengandung 40\% protein setiap pukul 09.00 WIB dan pukul 16.00 WIB. Suhu akuarium pemeliharaan diukur setiap 5 hari untuk pengecekan. Tiga puluh ikan pada masing-masing perlakuan diukur panjang tubuhnya di hari ke $10 \mathrm{dpf}$ dan hari ke-35 dpf untuk mengetahui pertumbuhan ikan. Enam ikan umur 35 dpf dari masing-masing perlakuan difiksasi dalam alkohol 70\% untuk pembuatan sediaan histologis dengan metode paraffin dengan pewarnaan Haematoxylin-Eosin. Data sintasan ikan data pertumbuhan berupa panjang ikan dianalisis menggunakan ANOVA. Data diferensiasi gonad dianalisis secara deskriptif. Hasil: Pertumbuhan ikan pada semua kelompok perlakuan dan kontrol tidak terdapat perbedaan yang nyata. Rata-rata sintasan ikan di semua kelompok perlakuan dan kontrol adalah $100 \%$. Pengamatan terhadap gonad menunjukkan bahwa gonad belum terdiferensiasi di semua kelompok perlakuan dan kontrol. Kesimpulan: Kisaran suhu ruang hingga $33{ }^{\circ} \mathrm{C}$ mendukung pertumbuhan ikan Nilem dengan perkembangan gonad dalam tahap gonad indiferen. 


\section{Introduction}

Gonadal differentiation of teleost possesses higher plasticity than other vertebrates (Martinez-Bengocheaa et al., 2020). In mammals, gonadal determination onset in the embryonal stage and determines the next stages, i.e. testes and ovary formation and the formation of secondary sexual organ formation (Tang, F. et al., 2020). Differentiation of gonad is affected by several factors, either internal or external factors. Exogenous steroid existence affects the differentiation of gonad in a teleost (Martinez-Bengocheaa et al., 2020). The plasticity of the gonads in teleost and the effect of temperature on gonad differentiation have been investigated in tilapia. Increased temperature up to $34{ }^{\circ} \mathrm{C}$ has been shown to direct the differentiation of gonads into testes and cause masculinization in tilapia (Oreochromis niloticus) treated for ten days during the critical phase of gonadal differentiation (Tessema et al., 2006). Furthermore, the treatment temperatures up to $36{ }^{\circ} \mathrm{C}$ in genetically all-female (XX) tilapia larvae for ten days in the critical phase of gonad differentiation, resulted in male tilapia with functional testes (Habibah et al., 2017). Research of the effects of temperature has been extensively investigated on tilapia (Baroiller et al., 1995; D'Cotta et al., 2001; Habibah et al., 2017; Tessema et al., 2006; Wessels et al., 2014; Wessels \& Hörstgen-Schwark, 2007, 2011).

Nilem fish is an indigenous species of Indonesia which has substantial economic value (Syandri et al., 2017). Nilem fish, national scale production, is still not able to fulfil national needs. Various researches related to Nilem fish were carried out in order to increase this aspect of fish production, one of which is the aspect of growth through stocking density (Herawati et al., 2019), nutrition (Setyaningrum et al., 2017; Syandri et al., 2017) reproduction aspects such as Nilem fish fecundity (Netti Aryani \& Mardiah, 2017), Nilem fish spawning (Muchlisin, 2014), polyploidization (Eriani et al., 2017), gynogenesis (Zulhardi et al., 2016) and genetic variety (Azrita, Hafrijal Syandri, J. et al., 2014). Optimal growth of Nilem fish is determined by stocking density support growth, i.e. 100 fish/m2 (Herawati et al., 2019).

\section{Methods}

The research was conducted using experimental methods with a completely randomized design. The treatments tested were temperature ranges: $28-29{ }^{\circ} \mathrm{C}, 30$ $31{ }^{\circ} \mathrm{C}, 32-33{ }^{\circ} \mathrm{C}$ and room temperature as a control. The tools and materials used were Nilem fish age one day after fertilization (dpf), water in the aquarium, aquarium heater, black plastic aquarium coating, nets as aquarium coverings, aerators, thermometers, Petri dishes and millimetre measuring blocks for measuring fish body length, sample bottles, alcohol $70 \%$ as a fixative, solution and paraffin for histological preparations and Haematoxylin-Eosin staining, and microscopes for histological observation.

Nilem fish age one day after fertilization were obtained by assisted spawning using $O$. vittatus broodstock induction using a GnRH analogue (Ovaprim, $0.5 \mathrm{cc} / \mathrm{kg} \mathrm{BW}$ ). A total of 110 Nilem fish age one day after fertilization were exposed to 12 aquariums with the temperature adjusted according to the range tested. The heater was placed in an aquarium filled with water, 24 hours before treatment. The control group aquarium was not equipped with a heater.

Temperature treatment was carried out for 35 days. Every five days were measuring the temperature of the water in the aquarium. Fish were fed with $40 \%$ protein feed of approximately 5 grams every 09.00 am and 04.00 pm. On the first, tenth and 35th day, the fish's length was measured by placing the fish in a petri dish filled with water and placed on a millimetre block. Thirty fish were measured for body length. Six out of 30 sampling fish were killed and fixed in $70 \%$ alcohol solution for making histological preparations. The procedure for making histological preparations was carried out according to Wijayanti et al. (2017).

Growth data consist of body length were analyzed using the Anova test. The histological study results were analyzed descriptively; the gonad stages of the fish were analyzed according to Kobayashi et al. (2012).

\section{Results}

Growth of Nilem fish was represented by increasing of body length. There was no difference in the mean of body length in all treatment include the control temperature treatment (Table 1.).

Table 1. Growth of Nilem fish (O. vittatus) by mean of temperature

\begin{tabular}{crrr}
\hline \multirow{2}{*}{ Treatment } & \multicolumn{3}{c}{ Body length (mm) } \\
\cline { 2 - 4 } A & $1 \mathrm{dpf}$ & $10 \mathrm{dpf}$ & $35 \mathrm{dpf}$ \\
B & $3 \pm 0.00 \mathrm{a}$ & $5.3 \pm 0.4 \mathrm{~b}$ & $11.0 \pm 0.2 \mathrm{c}$ \\
C & $3 \pm 0.00 \mathrm{a}$ & $5.3 \pm 0.7 \mathrm{~b}$ & $11.5 \pm 0.2 \mathrm{c}$ \\
D & $3 \pm 0.00 \mathrm{a}$ & $5.3 \pm 0.4 \mathrm{~b}$ & $10.4 \pm 0.1 \mathrm{c}$ \\
& $3 \pm 0.00 \mathrm{a}$ & $5.2 \pm 0.7 \mathrm{~b}$ & $12.0 \pm 0.2 \mathrm{c}$ \\
\hline
\end{tabular}

A, B, C, D were $28-29{ }^{\circ} \mathrm{C}, 30-31{ }^{\circ} \mathrm{C}, 32-33{ }^{\circ} \mathrm{C}$ and room temperature respectively.

Histological study of Nilem fish gonad in all treatment, temperature and control were indifferent. Indifferent gonads were located along dorsal mesentery of body cavity precisely below the swim bladder (Figure 1). 


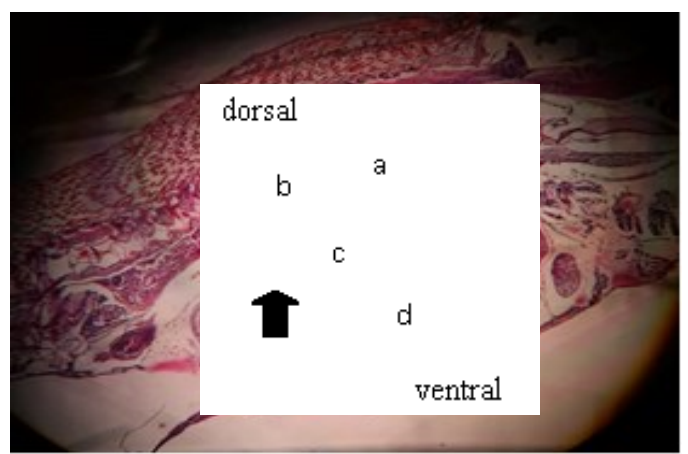

Figure 1. Histological preparation of sagittal section of Nilem fish body of $35 \mathrm{dpf}$ of the temperature treatment group. Gonad show by arrow, a= swim bladder, $b=$ kidney, $c=$ hepatopancreas, $d=$ intestine. Magnification of objective lens $=4 \times 10$.

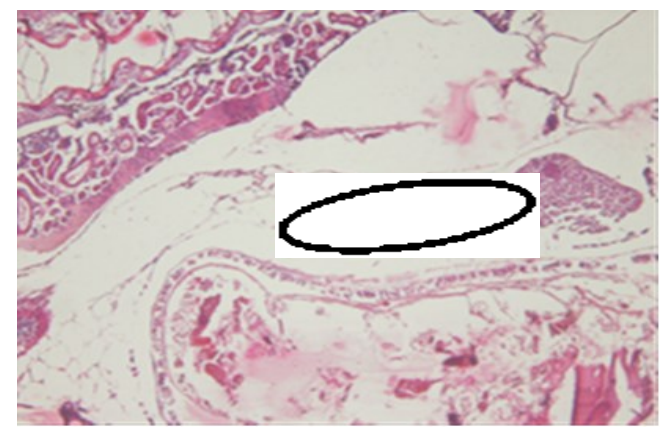

Figure 2. Histological preparation of sagittal section of Nilem fish $35 \mathrm{dpf}$ of a control group. Gonad showed by the ellipse. Magnification of the objective lens $=10 \times 10$.

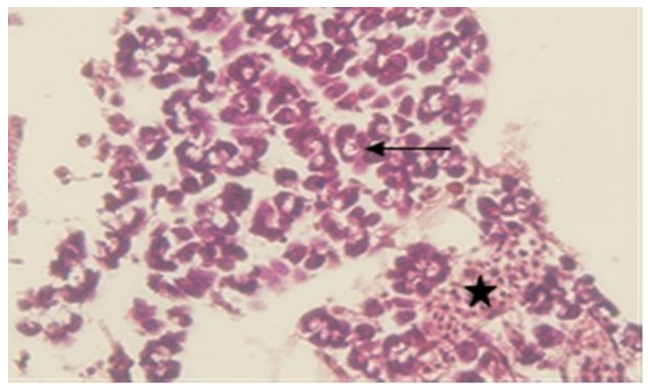

Figure 3. Histological preparation of gonad of Nilem fish of $35 \mathrm{dpf}$. Germ cells population with characteristics= strongly absorb the staining cells, a ratio of nucleus and cytoplasm were high and metachromatic nucleus. Arrow show the nucleus of the germ cell. Stars show the blood cells population within the blood vascular inside gonad. Magnification of objective lens $=40 \times 10$.

\section{Discussions}

Research result shows the subtle difference of growth amongst the treatment group and control group. The body length of all group, treatments and control possessed a similar range of body length. In teleost, zebrafish (Danio rerio), the temperature in the daily cycle affected the growth of zebrafish. Temperature below $28{ }^{\circ} \mathrm{C}$ supported growth, which supported fry production with low malformation and high survival rate (Villamizar et al., 2014). The previous study in temperature effects on the survival rate of Nilem fry (Habibah et al., 2019) produce a lethal temperature of $36^{\circ} \mathrm{C}$, and temperature tolerance of Nilem fry of $10 \mathrm{dpf}$ was $34^{\circ} \mathrm{C}$. The temperature range examined in this study were within the tolerance range for Nilem fry.

Study of the effect of temperature on the differentiation of gonad in Nilem fish requires a broad temperature range and time to know the timing of gonad differentiation of Nilem fish. Furthermore, the gonadal development of Nilem fish was able to elaborate.

Gonadal differentiation of teleost such as zebrafish is a complexes process with many factors inside (Liew and Orban, 2013) Gonadal differentiation was related to sex determination during the developmental stage, it determines by genetic factor, environment or both (Wilson et al., 2014).

Differentiation of gonad is part of gonad development. Gonadal development in some teleost was influenced by temperature. The high temperature was able to cease gonad activity in red Seabream fish (Pagrus (Chrysophrys) major) through the endocrine mechanism of the hypothalamus-pituitary-gonadal axis (Okuzawa \& Gen, 2013). The results showed that the gonads were not yet differentiated, gonads indifferent. Germ cell populations were found in indifferent gonads.

A germ cell is a candidate for oogonia in female individuals or spermatogonia in male individuals. Germ cells were characterized as cells that could absorb intense Haematoxylin-Eosin staining, metachromatic nucleus, and high ratio of nucleus to the cytoplasm. Germ cells were allocated outside the primordial gonads during embryonal development (Kobayashi et al., 2012) and could express Vasa (Nakamura et al., 2011). Research conducted by Pandit et al., (2015) explained the mechanism of germ cell reduction in tilapia gonads due to an increase in temperature of up to $37^{\circ} \mathrm{C}$ at several fish ages resulted from sterile individuals. In this study, the number of germ cells was not quantified. Based on the histological study, germ cells have not been differentiated into oogonia or spermatogonia. One indication of gonadal differentiation is that the germ cells reach a certain number of cells and the formation of an ovarian lumen in the differentiation of the gonads into the ovaries and efferent channels was formed in the gonads will differentiate into testes (Kobayashi et al., 2012). In this study, it was assumed that the age of $35 \mathrm{dpf}$ gonad was still indifferent. The gonad differentiation in tilapia occurs 20 days after the eggs hatch or equal to 24 dpf for ovarian differentiation and $29 \mathrm{dpf}$ for testicular differentiation (Kobayashi et al., 2012). Based on the results of the study, the Nilem fish gonads age $35 \mathrm{dpf}$ were indicated to have not yet experienced differentiation. Villamizar et al., (2014) Stated that the daily cycle of water 
temperature affected fish performance and sex differentiation in zebrafish. However, this is not entirely found in tilapia. Some of the germ cells in tilapia were not responsive to changes in water temperature (Baroiller et al., 2009).

\section{Conclusions}

The room temperature ranges up to $33^{\circ} \mathrm{C}$ supports the growth of Nilem fish with gonad development in the indifferent gonad stage, and survival reaches $100 \%$. This study's results implied that temperatures up to $33 \mathrm{oC}$ did not significantly affect the differentiation of Nilem fish gonads up to $35 \mathrm{dpf}$ of age.

\section{Acknowledgements}

The authors owe thanks to the Institute for Research and Community Service (LPPM) of Jenderal Soedirman University for funding research through the 2019 BLU funding scheme.

\section{Declaration statement}

The authors declare that they have no known competing financial interests or personal relationships that could have influenced the work reported in this paper.

\section{References}

Azrita, Hafrijal Syandri, J. (2014). Genetic variation among asang fish (Osteochilus vittatus Cyprinidae) populations using random amplified polymorphic DNA ( RAPD) markers. July.

Baroiller, J.-F., Chourrout, D., Fostier, A., \& Jalabert, B. (1995). Temperature and sex chromosomes govern sex ratios of the mouthbrooding Cichlid fish (Oreochromis niloticus). Journal of Experimental Zoology, 273(3), 216223. https://doi.org/10.1002/jez.1402730306

Baroiller, J. F., D'Cotta, H., \& Saillant, E. (2009). Environmental effects on fish sex determination and differentiation. Sexual Development, 3(2-3), 118-135. https://doi.org/10.1159/000223077

D'Cotta, H., Fostier, a, Guiguen, Y., Govoroun, M., \& Baroiller, J. F. (2001). Aromatase plays a key role during normal and temperature- induced sex differentiation of Tilapia Oreochromis niloticus. Molecular Reproduction and Development, 59(3), 265-276. https://doi.org/10.1002/mrd.1031

Eriani, K., Syahrin, A., Muchlisin, Z. A., \& Article, H. (2017). Biosaintifika Effect of Temperature Shock on the Triploidization Success. 9(2), 298-303. https://doi.org/10.15294/biosaintifika.v9i2.8680

Habibah, A N, Hana, \& Pratiwi, M. (2019). Perkembangan gonad benih ikan nilem yang dipelihara dalam temperatur berbeda. 1(November), 22-28.
Habibah, Aulidya N, \& Wilting, J. (2017). Germline Development of Genetically Female Nile Tilapia (Oreochromis niloticus) Reared under. https://doi.org/10.1159/000479396

Herawati, H., Hasan, Z., \& Rochima, E. (2019). Effect of Diffuser Aerator to Increase Growth of Nilem (Osteochilus vittatus) Cultivation With Different Density. March.

Kobayashi, Y., Nagahama, Y., \& Nakamura, M. (2012). Diversity and plasticity of sex determination and differentiation in fishes. Sexual Development, 7(1-3), 115-125. https://doi.org/10.1159/000342009

Liew, W. C. and O. (2013). Zebrafish sex: a complicated affair. https://doi.org/10.1093/bfgp/elt041

Martinez-Bengocheaa, 1, L. Dorettoa, 1, I.F. Rosaa, M.A. Oliveiraa, C. Silvaa, D.M.Z.A. Silvaa, G.R. Santosb, c, J.S.F. Santosb, c, M.M. Avelarb, c, L.V. Silvab, c, D. LucianelliJuniore, E.R.B. Souzab, C., R.C. Silvab, c, A.B. Stewartd, L.S.O. Nakaghib, c, F.N. Valentine,*, R. H. N., Santos, J. S. F., Avelar, M. M., Silva, L. V, Souza, E. R. B., Silva, R. C., Stewart, A. B., Nakaghi, L. S. O., Valentin, F. N., \& Nóbrega, R. H. (2020). Effects of $17 \beta$-estradiol on early gonadal development and expression of genes implicated in sexual differentiation of a South American teleost , Astyanax altiparanae Comparative Biochemistry and Physiology , Part B E ff ects of $17 \beta$ estradiol on early. Comparative Biochemistry and Physiology, Part B, 248-249(July), 110467. https://doi.org/10.1016/j.cbpb.2020.110467

Muchlisin, Z. A. (2014). Induced spawning of seurukan fish, Osteochilus vittatus (Pisces: Cyprinidae) using ovaprim, oxytocin and chicken pituitary gland extracts. November.

Nakamura, S., Kobayashi, K., Nishimura, T., \& Tanaka, M. (2011). Ovarian germline stem cells in the teleost fish, medaka (Oryzias latipes). International Journal of Biological Sciences, 7(4), 403-409.

Netti Aryani, 2, \& Ainul Mardiah, 2 Azrita and 2 Hafrijal Syandri 1. (2017). Fisheries and. December 2016. https://doi.org/10.3923/jfas.2017.29.35

Okuzawa, K., \& Gen, K. (2013). General and Comparative Endocrinology High water temperature impairs ovarian activity and gene expression in the brain - pituitary gonadal axis in female red seabream during the spawning season. General And Comparative Endocrinology, 194, 24-30. https://doi.org/10.1016/j.ygcen.2013.08.015

Pandit, N. P., Bhandari, R. K., Kobayashi, Y., \& Nakamura, M. (2015). High Temperature-Induced Sterility In The Female Nile Tilapia, Oreochromis niloticus. Gen Comp Endocrinol, 213, 110-117.

Setyaningrum, N., Hidayah, H. A., \& Article, H. (2017). Biosaintifika. 9(63), 257-264. https://doi.org/10.15294/biosaintifika.v9i2.9848

Syandri, H., Aryani, N., Mardiah., A., \& Azrita. (2017). Effects of Enrichment Commercial Feed with Different Fat Sources on Survival and Growth of Bonylip Barb (Osteochilus vittatus Cyprinidae) Fingerlings. 
J.Fish.Aquat.Sci., 12(1), 29-35.

Tang, F. Nainoa Richardson, Audrey Albina, M.-C. C. and A. P.-G. (2020). cells-09-01103-v2(1).pdf.part. Mdpi, 9(5).

Tessema, M., Müller-Belecke, A., \& Hörstgen-Schwark, G. (2006). Effect of rearing temperatures on the sex ratios of Oreochromis niloticus populations. Aquaculture, 258(1-4), 270-277. https://doi.org/10.1016/j.aquaculture.2006.04.041

Villamizar, N., Ribas, L., National, S., Piferrer, F., \& National, S. (2014). Impact of Daily Thermocycles on Hatching Rhythms, Larval Performance and Impact of Daily Thermocycles on Hatching Rhythms, Larval Performance and Sex Differentiation of Zebrafish, (May). https://doi.org/10.1371/journal.pone.0052153

Wessels, S., \& Hörstgen-Schwark, G. (2007). Selection experiments to increase the proportion of males in Nile tilapia (Oreochromis niloticus) by means of temperature treatment. Aquaculture, 272(SUPPL. 1). https://doi.org/10.1016/j.aquaculture.2007.08.009

Wessels, S., \& Hörstgen-Schwark, G. (2011). Temperature dependent sex ratios in selected lines and crosses with a YY-male in Nile tilapia (Oreochromis niloticus). Aquaculture, 318(1-2), 79-84 https://doi.org/10.1016/j.aquaculture.2011.04.039

Wessels, S., Sharifi, R. A., Luehmann, L. M., Rueangsri, S., Krause, I., Pach, S., Hoerstgen-Schwark, G., \& Knorr, C. (2014). Allelic variant in the anti-müllerian hormone gene leads to autosomal and temperature-dependent sex reversal in a selected nile tilapia line. PLOS ONE, 9(8). https://doi.org/10.1371/journal.pone.0104795

WIjayanti, et al. (2017). A Simple Paraffin Embedded Protocol For Fish Egg, Embryo , And Larvae. 4, 85-89.

Wilson, C. A., High, S. K., McCluskey, B. M., Amores, A., Yan, Y. L., Titus, T. A., Anderson, J. L., Batzel, P., Carvan, M. J., Schartl, M., \& Postlethwait, J. H. (2014). Wild sex in zebrafish: Loss of the natural sex determinant in domesticated strains. In Genetics (Vol. 198, Issue 3). https://doi.org/10.1534/genetics.114.169284

Zulhardi Zulhardi*, Zainal A. Muchlisin, S. P. (2016). Effect of Zygote Age for Heat Shocking on The Successful of Gynogenesis of Pengaruh Umur Zigot Pada Saat Kejutan Panas Terhadap Keberhasilan Ginogenesis Ikan Seurukan (Osteochilus Vittatus) Effect of Zygote Age for Heat Shocking on The Successful of Gyn. December. 